\title{
INDEKS PEMBANGUNAN MANUSIA DI MADURA: ANALISIS TIPOLOGI KLASSEN
}

\author{
Oleh: \\ Indah Purnama Sari ${ }^{1}$ \\ Bado Riyono ${ }^{2}$ \\ Agus Supandi ${ }^{3}$ \\ Program Studi Pendidikan Ekonomi \\ Fakultas llmu Pendidikan dan Pengetahuan Sosial ${ }^{1,2}$ \\ Program Studi Pendidikan Matematika \\ Fakultas Matematika dan Ilmu Pengetahuan Alam ${ }^{3}$ \\ Universitas Indraprasta PGRI \\ Email: \\ indah.purnamasari@unindra.ac.id, ${ }^{1}$
}

\begin{abstract}
ABSTRAK
Penelitian ini bertujuan untuk menganalisis Indeks Pembangunan Manusia di Madura berdasarkan tipologi klassen. Indeks Pembangunan Manusia adalah salah satu indikator penting dalam mengukur kesejahteraan masyarakat. Pulau Madura menarik untuk diteliti karena berdasarkan Indeks Pembangunan Manusia, Kabupatenkabupaten di Madura menempati rangking terendah diantara kota dan kabupaten lainnya di Jawa Timur. Metode penelitian yang digunakan untuk menjawab permasalahan adalah metode triangulasi, menggunakan data sekunder dari Badan Pusat Statistik empat kabupaten di Pulau Madura, yaitu Kabupaten Bangkalan, Kabupaten Sampang, Kabupaten Pamekasan, dan Kabupaten Sumenep dan data primer hasil wawancara dengan beberapa nara sumber. Hasil penelitian menunjukkan bahwa tipologi pertumbuhan ekonomi di Pulau Madura terbagi menjadi tiga kuadran, yaitu : 1) Kuadran I (daerah cepat maju dan cepat tumbuh) adalah Kabupaten Pamekasan, 2) Kuadran III (daerah tertekan) adalah Kabupaten Sumenep, dan 3) Kuadran IV (daerah relatif tertinggal) adalah Kabupaten Bangkalan dan Kabupaten Sampang. Kabupaten Pamekasan mengalami peningkatan kualifikasi dari lima tahun sebelumnya, Kabupaten Sumenep dan Kabupaten Sampang stagnan, adapun Kabupaten Bangkalan justru mengalami kemunduran.
\end{abstract}

Kata Kunci: Indeks Pembangunan Manusia, Madura, Tipologi Klassen 


\section{A. PENDAHULUAN}

Pada tanggal 6-8 September 2000 di New York, Amerika Serikat berlangsung Konferensi Tingkat Tinggi Perserikatan Bangsa-Bangsa (PBB) yang dihadiri oleh kepala negara dan kepala pemerintahan dari 189 negara anggota PBB. Konferensi ini menghasilkan kesepakatan untuk menciptakan dunia yang lebih sejahtera, adil serta damai. Kesepakatan ini kemudian menjadi awal dari pembentukan tujuan pembangunan milenium (Millenium Development Goals/MDGs).

MDGs adalah sebuah paradigma pembangunan global dengan delapan tujuan pembangunan milenium, meliputi : 1) menanggulangi kemiskinan dan kelaparan, 2) mencapai pendidikan dasar untuk semua, 3) mendorong kesetaraan gender dan pemberdayaan perempuan, 4) menurunkan angka kematian anak, 5) meningkatkan kesehatan ibu, 6) memerangi HIV/AIDS, malaria, dan penyakit menular lainnya, 7) memastikan kelestarian lingkungan hidup, dan 8) mengembangkan kemitraan global untuk pembangunan (Todaro \& Smith, 2016).

Indonesia sebagai salah satu negara yang ikut menandatangani Deklarasi MDGs, mempunyai komitmen untuk melaksanakan program-program MDGs sebagai bagian tak terpisahkan dari program pembangunan nasional baik jangka pendek, menengah, dan panjang. Pembangunan nasional merupakan serangkaian upaya pembangunan yang berkesinambungan, meliputi seluruh kegiatan di dalam kehidupan masyarakat, bangsa, dan negara dalam upaya meningkatkan pembangunan yang lebih baik. Indonesia telah menjadikan pencapaian MDGs sebagai salah acuan penting terhadap penyusunan Dokumen Perencanaan Pembangunan Nasional. Oleh karena itu, komitmen Indonesia untuk mencapai target-target yang terdapat dalam MDGs, sudah sesuai dengan komitmen negara ini untuk meningkatkan kesejahteraan rakyatnya serta memberikan kontribusi kepada peningkatan kesejahteraan masyarakat dunia. Komitmen Indonesia tersebut secara nyata terealisasi dengan keberhasilan Indonesia mencapai beberapa target dalam tujuan MDGs yakni: 1) Tujuan ke-2: Mencapai Pendidikan Dasar untuk Semua, terbukti dengan telah diterapkannya pendidikan dasar 9 (Sembilan) tahun di Indonesia; 2) Tujuan ke-3: Mendorong Kesetaraan Gender dan Pemberdayaan Perempuan, dilihat dari Rasio Angka Partisipasi Murni (APM) perempuan terhadap laki-laki di SD/MI/Paket A dan SMA/MTs/Paket B, kontribusi perempuan dalam pekerjaan upahan di sektor nonpertanian, maupun proporsi kursi yang diduduki perempuan di DPR; 3) Tujuan ke-4: Menurunkan Angka Kematian Anak, dimana angka kematian balita di Indonesia telah mengalami penurunan yang signifikan serta peningkatan juga terdapat pada jumlah persentase anak usia 1 tahun yang diimunisasi campak (Lisbet, 2013).

Di dalam pembangunan, perkembangan wilayah merupakan suatu hal yang harus diterima dengan segala kemungkinan permasalahan yang akan ditimbulkan. Perkembangan wilayah dapat terjadi karena adanya suatu perkembangan peradaban dan tuntutan kebutuhan manusia yang semakin meningkat. Pembangunan atau pengembangan wilayah dapat dirumuskan sebagai rangkaian upaya untuk mewujudkan keterpaduan dalam penggunaan berbagai sumber daya, merekatkan dan 
menyeimbangkan pembangunan, dan meningkatkan keserasian antar kawasan (Latuconsina, 2017). Suatu wilayah sebagai kumpulan dari wilayah-wilayah yang kecil dengan segala potensi dan daya tarik serta daya dorong yang berbeda-beda mengharuskan antar wilayah ini untuk saling berinteraksi sehingga nantinya mendapatkan manfaat sebesar-besarnya untuk kepentingan masyarakat di wilayah tersebut.

Paradigma pembangunan yang sedang berkembang saat ini adalah pertumbuhan ekonomi, yang salah satunya diukur dengan pembangunan manusia. Sebagaimana diketahui, pertumbuhan ekonomi jangka panjang suatu negara tidak hanya didukung oleh kenaikan stok modal fisik dan jumlah tenaga kerja, tetapi juga peningkatan mutu modal manusia yang memiliki pengaruh kuat terhadap peningkatan kualitas tenaga kerja serta pemanfaatan kemajuan teknologi. Pembangunan manusia ini dapat dilakukan dengan meningkatkan kualitas manusia, meliputi beberapa aspek yang penting seperti usia hidup, pendidikan, dan standar hidup layak. Berdasarkan beberapa aspek tersebut, United Nation Development Programme (UNDP) telah menetapkan standar pengukuran pembangunan sumber daya manusia yang dituangkan ke dalam Human Development Indeks (HDI) atau Indeks Pembangunan Manusia (IPM). Indeks Pembangunan Manusia (IPM) diukur melalui tiga dimensi, yaitu: pendidikan, kesehatan, dan standar hidup layak.

IPM pada dasarnya juga merupakan ukuran untuk melihat dampak kinerja pembangunan wilayah yang dimensinya sangat luas, salah satunya adalah taraf kualitas fisik dan non fisik penduduk. Kualitas fisik tercermin dari angka harapan hidup sedangkan kualitas non fisik melalui lamanya rata-rata penduduk bersekolah dan angka melek huruf (Lumbantoruan \& Hidayat, 2014).

Pembangunan manusia tidak berdiri sendiri, melainkan memiliki hubungan saling terkait dan saling berkontribusi dengan pertumbuhan ekonomi. UNDP mengungkapkan bahwa pembangunan manusia dapat berkesinambungan apabila didukung oleh pertumbuhan ekonomi. Walaupun keduanya tidak memiliki hubungan secara langsung, namun apabila kedua hal tersebut disatukan pada suatu kebijakan pembangunan yang searah maka akan tercipta suatu kekuatan yang dapat saling mendorong sehingga pertumbuhan ekonomi akan sangat efektif untuk memperbaiki pembangunan manusia (Bemby \& Bashir, 2015). Kebijakan pembangunan yang searah ini dapat didukung oleh adanya data tipologi suatu wilayah, yang mampu menjelaskan ciri dan tingkat perkembangan suatu wilayah terhadap wilayah yang lain dan atau kemiripan ciri antar wilayah. Data tipologi akan memudahkan pemerintah dalam melakukan clusterisasi dalam rangka percepatan dan pemerataan pembangunan. Hal ini karena umumnya wilayah-wilayah yang berada pada satu cluster memiliki bentuk hambatan dan tantangan yang sama.

Madura adalah wilayah bagian dari Provinsi Jawa Timur. Secara umum, wilayah Provinsi Jawa Timur dibagi menjadi 2 bagian besar yaitu Jawa Timur Daratan dan Pulau Madura. Luas wilayah Jawa Timur daratan mencakup 90 persen dari seluruh luas wilayah Provinsi Jawa Timur, sedangkan luas Pulau Madura hanya sekitar 10 persen. Luas wilayah Provinsi Jawa Timur yang mencapai 47.799,75 km2 
habis terbagi menjadi 38 Kabupaten/Kota, 29 Kabupaten dan 9 Kota (Badan Pusat Statistik Provinsi Jawa Timur, 2018). Propinsi Jawa Timur terbagi lagi menjadi beberapa koridor yang meliputi kabupaten/kota yang ada di Propinsi Jawa Timur, yaitu: Koridor Utara Selatan terdiri dari Gresik - Surabaya - Sidoarjo - Mojokerto Pasuruan - Malang - Blitar. Koridor Barat Daya terdiri dari Jombang - Kediri Tulungagung - Trenggalek - Nganjuk - Madiun - Ponorogo - Pacitan - Magetan. Koridor Timur terdiri dari Probolinggo - Situbondo - Bondowoso - Lumajang Jember - Banyuwangi. Koridor Utara terdiri dari Lamongan - Tuban - Bojonegoro Ngawi - Bangkalan - Sampang - Pamekasan - Sumenep.

Sebagaimana Provinsi Jawa Timur sangat menarik dikaji karena konsisten sebagai penyumbang PDB terbesar ke dua terhadap PDB Indonesia (Kuncoro, 2019), Pulau Madura sebagai bagian dari Provinsi Jawa Timur juga menarik untuk dikaji. Hal ini karena kendati telah dibangun Jembatan Suramadu yang menghubungkan Pulau Jawa dengan Pulau Madura, belum terjadi peningkatan secara signifikan dalam hal pembangunan, salah satunya berdasarkan indikator IPM Pulau Madura selalu menempati urutan terendah di Jawa Timur. Hal ini menunjukkan bahwa Pulau Madura relatif tertinggal dibandingkan kabupaten lainnya di Jawa Timur. Analisis tipologi ini dilakukan untuk menentukan clusterisasi kabupaten-kabupaten di Madura sehingga dapat dirumuskan kebijakan yang tepat dalam rangka pemerataan dan percepatan pembangunan.

\section{B. KAJIAN PUSTAKA}

\section{Pertumbuhan Ekonomi}

Pertumbuhan ekonomi merupakan suatu proses perubahan kondisi perekonomian suatu Negara yang bersifat positif dan berkesinambungan dalam suatu periode tertentu. Pertumbuhan ekonomi menurut Kuznets adalah kenaikan jangka panjang dalam kemampuan suatu negara untuk menyediakan semakin banyak jenis barang-barang ekonomi kepada penduduknya. Adapun faktor-faktor yang mempengaruhi pertumbuhan ekonomi antara lain adalah : sumber daya manusia, sumber daya alam, ilmu pengetahuan dan teknologi, budaya, dan modal (Lumbantoruan \& Hidayat, 2014).

Terdapat tiga komponen pertumbuhan ekonomi yang paling penting, yaitu : 1) akumulasi modal mencakup semua investasi baru (lahan, peralatan fisik, sumber daya manusia) melalui peningkatan kesehatan, pendidikan, dan keterampilan kerja; 2) pertumbuhan populasi yang memicu pertumbuhan angkatan kerja; serta 3) kemajuan teknologi yang melahirkan inovasi untuk mempercepat suatu pekerjaan (Todaro \& Smith, 2016). Dengan demikian, pertumbuhan ekonomi merupakan salah satu indikasi keberhasilan pembangunan ekonomi yang salah satunya ditandai dengan peningkatan kesejahteraan masyarakat. 


\section{Pembangunan Ekonomi}

Pembangunan ekonomi merupakan proses multidimesi yang melibatkan berbagai perubahan mendasar dalam struktur sosial, sikap masyarakat dan lembaga nasional, percepatan pertumbuhan dan pengurangan ketimpangan serta penanggulangan kemiskinan. Pembangunan ekonomi pada hakikatnya harus mencerminkan perubahan sistem sosial secara total untuk mengubah kondisi kehidupan dari yang dipandang tidak memuaskan menjadi lebih baik secara lahir dan batin.

Terdapat tiga nilai inti dalam pembangunan ekonomi, yaitu : 1) kecukupan, yaitu kemampuan untuk memenuhi kebutuhan dasar meliputi makanan, pakaian, dan tempat tinggal; 2) harga diri, yaitu perasaan berharga yang dinikmati suatu masyarakat jika sistem dan lembaga sosial, politik, dan ekonominya menjunjung tinggi nilai-nilai kemanusiaan seperti kehormatan, martabat, integritas, dan kemandirian; dan 3) kebebasan, yaitu situasi yang menunjukkan bahwa suatu masyarakat memiliki berbagai alternative untuk memuaskan keinginannya dan setiap orang dapat mengambil pilihan riil sesuai keinginannya (Todaro \& Smith, 2016). Dengan demikian, pembangunan ekonomi pada dasarnya meliputi pembangunan fisik dan keadaan mental masyarakat untuk mewujudkan kehidupan yang lebih baik.

\section{Indeks Pembangunan Manusia}

Indeks Pembangunan Manusia (IPM) diperkenalkan pertama kali pada tahun 1990 oleh United Nations Development Programme. Saat itu IPM dibentuk dari empat indikator yaitu : angka harapan hidup saat lahir, angka melek huruf, gabungan angka partisipasi kasar, dan Produk Domestik Bruto (PDB) per kapita. Keempat indikator ini merefleksikan dimensi umur panjang dan hidup sehat, pengetahuan dan standar hidup layak. Sejak saat itu IPM secara berkala dipublikasikan setiap tahun dalam suatu Laporan Pembangunan Manusia (Human Development Report).

IPM kemudian menjadi indikator penting dalam mengukur kemajuan pembangunan manusia dan diadopsi oleh berbagai negara termasuk Indonesia. Indonesia pertama kali menghitung IPM pada tahun 1996, dilakukan secara berkala per tiga tahun sekali. Namun mulai tahun 2004 IPM dihitung setiap tahun menggunakan empat indikator, yaitu : angka harapan hidup saat lahir, angka melek huruf, rata-rata lama sekolah, dan pengeluaran per kapita.

Pada tahun 2010 UNDP mengembangkan gagasan baru mengenai metode penghitungan IPM, yaitu menggunakan indikator baru meliputi : indikator angka melek huruf, dan indikator gabungan angka partisipasi kasar diganti dengan indikator harapan lama sekolah dan rata-rata lama sekolah. Indikator PDB per kapita diganti dengan Produk Nasional Bruto (PNB) per kapita. Selain itu menggunakan cara penghitungan baru dimana perhitungan rata-rata indeks yang awalnya aritmatik diubah menjadi rata-rata geometrik.

Indonesia mengadopsi penghitungan IPM yang baru mulai tahun 2014 dengan menggunakan indikator yang sama dengan UNDP, kecuali PNB per kapita, diproksi 
dengan pengeluaran per kapita. Untuk menjaga kesinambungan Indonesia merilis angka IPM baru mulai tahun 2010 hingga tahun 2014 dan dihitung hingga tingkat kabupaten/kota (Badan Pusat Statistik, 2015).

\section{METODE PENELITIAN}

Ruang lingkup penelitian meliputi empat kabupaten di Pulau Madura, yaitu: Kabupaten Bangkalan, Kabupaten Sampang, Kabupaten Pamekasan, dan Kabupaten Sumenep. Data yang digunakan adalah data sekunder dari Badan Pusat Statistik, dan data primer hasil wawancara dengan beberapa nara sumber. Penelitian ini menggunakan metode triangulasi. Untuk mempermudah dalam analisis dalam penelitian ini menggunakan Tipology Klassen sehingga diketahui karakteristik tentang pola dan struktur pertumbuhan ekonomi dan pembangunan manusia di Pulau Madura.

Setiap daerah memiliki karakteristik yang berbeda dalam hal kemajuan dan pertumbuhan ekonomi. Ada daerah yang mampu memacu pertumbuhan ekonomi secara cepat dengan mengeksplorasi semua potensi wilayah, sebaliknya ada daerah yang mengalami stagnansi bahkan mengalami penurunan. Untuk dapat membandingkan tingkat kemajuan suatu daerah dengan daerah lain dalam suatu lingkup referensi yang sama misal dalam satu provinsi, dapat menggunakan analisis tipologi klassen melalui matriks berikut :

Tabel 1.

Klasifikasi Daerah Menurut Tipologi Klassen

\begin{tabular}{|c|c|c|c|}
\hline $\mathrm{r}$ & $\mathrm{y}$ & $y i>y$ & yi $<y$ \\
\hline \multirow{2}{*}{\multicolumn{2}{|c|}{ ri $>r$}} & Kuadran I & Kuadran II \\
\hline & & $\begin{array}{l}\text { Daerah Cepat Maju dan } \\
\text { Cepat Tumbuh }\end{array}$ & Daerah Berkembang Cepat \\
\hline & $\mathrm{ri}<\mathrm{r}$ & Kuadran III & Kuadran IV \\
\hline & & $\begin{array}{c}\text { Daerah Maju tetapi } \\
\text { Tertekan }\end{array}$ & Daerah Relatif Tertinggal \\
\hline
\end{tabular}

Sumber : Lumbantoruan \& Hidayat, 2014

Keterangan :

ri : Laju pertumbuhan ekonomi wilayah i

yi : IPM wilayah i

$\mathrm{r} \quad$ : Laju pertumbuhan ekonomi wilayah referensi

y : IPM wilayah referensi

Tipologi Klassen melakukan pengelompokan wilayah berdasarkan dua karakteristik yang dimiliki daerah tersebut, yaitu Indeks Pembangunan Manusia (IPM) dan laju pertumbuhan ekonomi. Melalui analisis tipologi klassen dapat 
diperoleh empat karakteristik wilayah, yaitu : 1) daerah maju dan bertumbuh cepat (rapid growth region), 2) daerah sedang bertumbuh atau berkembang cepat (growing region), 3) daerah maju tapi tertekan (retarded region), dan 4) daerah relatif tertinggal (relatively backward region) (Lumbantoruan \& Hidayat, 2014).

\section{HASIL DAN PEMBAHASAN}

\section{Pertumbuhan Ekonomi di Pulau Madura}

Pulau Madura merupakan salah satu kepulauan di Provinsi Jawa Timur yang terdiri dari empat kabupaten, yaitu Kabupaten Bangkalan, Kabupaten Sampang, Kabupaten Pamekasan, dan Kabupaten Sumenep. Keempat kabupaten ini tergolong kabupaten yang tertinggal bila dibandingkan dengan wilayah sekitarnya, sebagaimana tabel berikut:

Tabel 2.

Laju Pertumbuhan Produk Domestik Regional Bruto Atas Dasar Harga Konstan 2010 Menurut Kabupaten/Kota di Provinsi Jawa Timur Wilayah Koridor Utara Periode 2014-2017

\begin{tabular}{clcccc}
\hline No & Kabupaten/Kota & $\mathbf{2 0 1 4}$ & $\mathbf{2 0 1 5}$ & $\mathbf{2 0 1 6}$ & $\mathbf{2 0 1 7}$ \\
\hline 1 & Kab Lamongan & 6,30 & 5,77 & 5,86 & 5,52 \\
2 & Kab Tuban & 5,47 & 4,89 & 4,90 & 5,00 \\
3 & Kab Bojonegoro & 2,29 & 17,42 & 21,95 & 10,26 \\
4 & Kab Ngawi & 5,82 & 5,08 & 5,21 & 5,07 \\
5 & Kab Bangkalan & 7,19 & $-2,66$ & 0,66 & 3,53 \\
6 & Kab Sampang & 0,08 & 2,08 & 6,17 & 4,69 \\
7 & Kab Pamekasan & 5,62 & 5,32 & 5,35 & 5,35 \\
8 & Kab Sumenep & 6,23 & 1,27 & 2,58 & 2,86 \\
\hline
\end{tabular}

Sumber : diolah dari BPS Jatim, 2018

Berdasarkan data tersebut, dapat dihitung rata-rata pertumbuhan ekonomi di Pulau Madura sebagai berikut :

Tabel 3.

Rata-rata Pertumbuhan Ekonomi Kabupaten di Pulau Madura

\begin{tabular}{clccccc}
\hline No & Kabupaten/Kota & $\mathbf{2 0 1 4}$ & $\mathbf{2 0 1 5}$ & $\mathbf{2 0 1 6}$ & $\mathbf{2 0 1 7}$ & $\begin{array}{c}\text { Rata-rata } \\
\text { kabupaten }\end{array}$ \\
\hline 1 & Kab Bangkalan & 7,19 & $-2,66$ & 0,66 & 3,53 & 2,18 \\
2 & Kab Sampang & 0,08 & 2,08 & 6,17 & 4,69 & 3,26 \\
3 & Kab Pamekasan & 5,62 & 5,32 & 5,35 & 5,35 & 5,41 \\
4 & Kab Sumenep & 6,23 & 1,27 & 2,58 & 2,86 & 3,24 \\
Jumlah & & & & & 14,09 \\
Rata-rata pulau & & & & & 3,53 \\
\hline
\end{tabular}

Sumber : diolah dari BPS Jatim, 2018 
Berdasarkan hasil perhitungan pada Tabel 3, rata-rata pertumbuhan ekonomi di Pulau Madura hanya sebesar 3,53. Angka ini terpaut cukup jauh dari rata-rata pertumbuhan ekonomi Provinsi Jawa Timur mulai periode tahun 2014 hingga tahun 2017, sebagaimana diagram berikut:

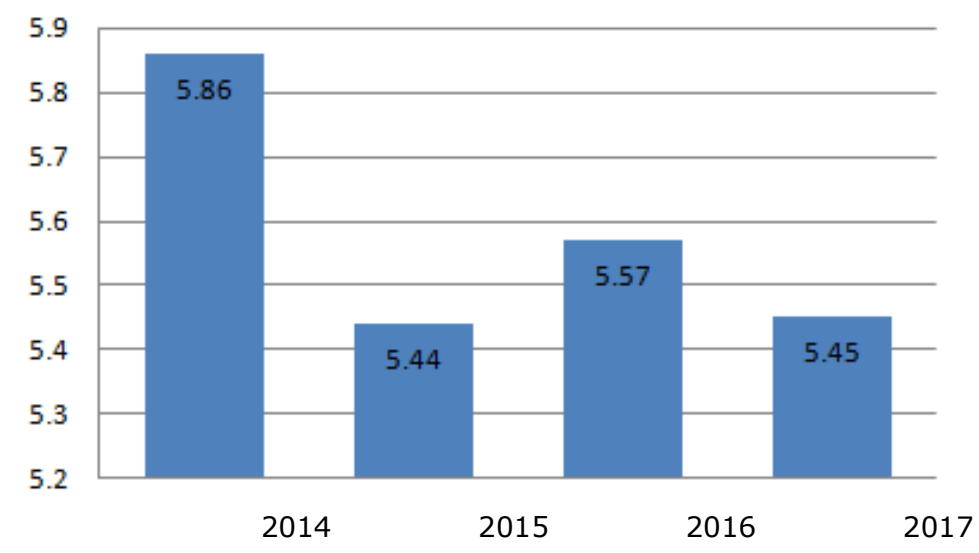

Gambar 1.

Rata-rata Pertumbuhan Ekonomi Provinsi Jawa Timur Periode 2014-2017 Sumber : BPS Jatim, 2018

\section{Perkembangan Indeks Pembangunan Manusia di Pulau Madura}

Berikut ini adalah data Indeks Pembangunan Manusia di Pulau Madura, sebagaimana pada Tabel 4.

Tabel 4.

Rata-rata Indeks Pembangunan Manusia di Pulau Madura

\begin{tabular}{cllcccc}
\hline No & Kabupaten/Kota & $\mathbf{2 0 1 4}$ & $\mathbf{2 0 1 5}$ & $\mathbf{2 0 1 6}$ & $\mathbf{2 0 1 7}$ & $\begin{array}{c}\text { Rata-rata } \\
\text { kabupaten }\end{array}$ \\
\hline 1 & Kab Bangkalan & 60,71 & 61,49 & 62,06 & 62,30 & 61,64 \\
2 & Kab Sampang & 56,98 & 58,18 & 59,09 & 59,90 & 58,54 \\
3 & Kab Pamekasan & 62,66 & 63,10 & 63,98 & 64,93 & 63,67 \\
4 & Kab Sumenep & 61,43 & 62,38 & 63,42 & 64,28 & 62,88 \\
Jumlah & & & & 246,73 \\
Rata-rata pulau & & & & 61,68 \\
\hline \multicolumn{3}{l}{ Sumber : diolah dari berbagai sumber }
\end{tabular}

Berdasarkan tabel di atas, level Indeks Pembangunan Madura secara rata-rata di Pulau Madura berada pada kategori "Sedang", namun IPM Kabupaten Sampang justru berada pada kategori "Rendah". Hal ini merupakan sebuah ketimpangan, mengingat posisi Kabupaten Sampang berada di tengah-tengah Kabupaten Bangkalan dan Kabupaten Pamekasan. Terlebih jika dibandingkan dengan IPM Jawa Timur yang mencapai 70,27 pada tahun 2017 kemudian meningkat menjadi 70,77 pada tahun 2018 (BPS Kabupaten Bangkalan, 2018). Angka IPM yang diraih oleh Provinsi Jawa 
Timur menunjukkan secara rata-rata IPM Jawa Timur berada pada kategori "Baik". Data IPM ini lebih menguatkan pendapat bahwa kabupaten di Pulau Madura secara umum mengalami masalah dalam pembangunan manusia.

\section{Klasifikasi Daerah Menurut Analisis Tipologi Klassen}

Analisis tipologi klassen digunakan untuk mengetahui gambaran tentang pola pertumbuhan ekonomi pada daerah kota atau kabupaten. Tipologi klassen pada dasarnya membagi daerah berdasar dua indikator utama, yaitu pertumbuhan ekonomi daerah dan pendapatan perkapita daerah, namun pada penelitian pendapatan perkapita daerah diproksi dengan angka Indeks Pembangunan Manusia (IPM). Adapun pertumbuhan ekonomi didapatkan dari data pertumbuhan Produk Domestik Regional Bruto (PDRB).

Kriteria yang digunakan untuk membagi daerah kabupaten dalam penelitian ini adalah : Pertama, Daerah Cepat Maju dan Cepat Tumbuh (High Growth and High Human Development Indeks/HDI) yaitu daerah yang memiliki tingkat pertumbuhan ekonomi dan IPM yang lebih tinggi dibandingkan rata-rata Pulau Madura. Kedua, Daerah Berkembang Cepat (High Growth but Low HDI) yaitu daerah yang memiliki tingkat pertumbuhan ekonomi tinggi tetapi IPM lebih rendah dibandingkan rata-rata Pulau Madura. Ketiga, Daerah Maju tetapi Tertekan (High HDI but Low Growth) yaitu daerah yang memiliki IPM lebih tinggi tetapi tingkat pertumbuhan ekonominya lebih rendah dibandingkan rata-rata Pulau Madura. Keempat, Daerah Relatif Tertinggal (Low Growth and Low HDI) yaitu daerah yang memiliki tingkat pertumbuhan ekonomi dan IPM yang lebih rendah dibandingkan rata-rata Pulau Madura.

Berdasarkan hasil penelitian bahwa rata-rata pertumbuhan ekonomi di Pulau Madura periode 2014-2017 adalah 3,53. Adapun rata-rata IPM periode 2014-2017 adalah 61,68. Dengan demikian, dapat digambarkan matriks tipologi klassen sebagai berikut :

Tabel 5.

Matriks Tipologi Klassen

\begin{tabular}{ccc}
\hline Pert. Ekonomi & IPM & IPMi $<$ IPMy \\
\hline $\begin{array}{c}\text { Pertumbuhan i }> \\
\text { Pertumbuhan y }\end{array}$ & $\begin{array}{c}\text { Kuadran I } \\
\text { Daerah Cepat Maju dan } \\
\text { Cepat Tumbuh }\end{array}$ & $\begin{array}{c}\text { Kuadran II } \\
\text { Daerah Berkembang } \\
\text { Cepat }\end{array}$ \\
$\begin{array}{c}\text { Kabupaten Pamekasan } \\
\text { Pertumbuhan i }<\end{array}$ & Kuadran III \\
Daerah Maju tetapi & Daerah Relatif Tertinggal \\
\hline
\end{tabular}


Tertekan

Kabupaten Sumenep

Kabupaten Bangkalan Kabupaten Sampang

Berdasarkan matriks tersebut, diperoleh beberapa temuan, yaitu :

1. Kabupaten Pamekasan berada di kuadran I dengan kategori daerah yang cepat maju dan cepat tumbuh.

Hal ini sangat menarik untuk dikaji lebih mendalam mengingat untuk mencapai Kabupaten Pamekasan harus melalui dua kabupaten sebelumnya, yaitu Kabupaten Bangkalan dan Kabupaten Sampang (secara geografis memiliki jarak yang cukup jauh dengan Ibu Kota Provinsi Jawa Timur, yaitu Surabaya).

Temuan ini juga selaras dengan pandangan masyarakat mengenai Kabupaten Pamekasan. Berdasarkan hasil wawancara, masyarakat Madura menilai bahwa Kabupaten yang dipandang paling maju diantara empat kabupaten di Madura adalah Kabupaten Pamekasan. Beberapa alasan yang dikemukakan adalah: sekolah unggulan dengan sistem asrama pertama kali di Madura muncul di Kabupaten Pamekasan, yaitu menetapkan SMA Negeri 3 Pamekasan sebagai sekolah unggulan, saat ini dikenal dengan nama SMA Negeri 3 Unggulan Tenggarong, Pamekasan. Alasan yang lain adalah beberapa tokoh nasional yang terkenal banyak dari dari Kabupaten Pamekasan. Beberapa diantaranya adalah Prof. Dr. Mohammad Mahfud MD.,S.H. (lahir di Sampang namun besar di Pamekasan, pernah menjabat sebagai Ketua Mahkamah Konstitusi, anggota DPR RI, Menteri Pertahanan di era Gus Dur), Jenderal TNI (Purn) Raden Hartono (pernah menjabat sebagai Kepala Staf TNI Angkatan Darat, Menteri Penerangan, dan Menteri Dalam Negeri di era Presiden Soeharto), serta Prof. Dr. Ir. Mien A. Rifai (Guru Besar IPB).

Lebih jauh tentang Kabupaten Pamekasan, selain dikenal sebagai Kota Batik, pada akhir tahun 2012 menteri Pendidikan dan Kebudayaan Moh. Nuh menobatkan secara resmi Kabupaten Pamekasan sebagai Kabupaten Pendidikan. Hal ini disebabkan banyaknya lembaga pendidikan mulai dari Tingkat Taman Kanak-kanak hingga Perguruan Tinggi. Predikat Kabupaten Pendidikan juga ditunjang oleh berbagai prestasi di bidang pendidikan baik dari tingkat lokal, regional, hingga internasional.

Pada zaman kerajaan sebelum Indonesia merdeka, Pamekasan pernah menjadi pusat pemerintahan di Madura, sebelum akhirnya pusat pemerintahan dipindah ke Sumenep.

2. Tidak ada yang masuk ke dalam kuadran II dengan kategori daerah berkembang cepat dengan indikator IPM lebih rendah dari rata-rata namun pertumbuhan ekonominya lebih tinggi dari rata-rata. 
3. Kabupaten Sumenep berada di kuadran III sebagai daerah maju tetapi tertekan dengan indikator IPM lebih tinggi dari IPM rata-rata Madura, namun laju pertumbuhan ekonominya lebih rendah dari rata-rata Madura.

Sebagaimana diketahui, secara geografis Kabupaten Sumenep terletak di ujung timur Pulau Madura. Untuk mencapai Kabupaten ini harus melalui tiga kabupaten sebelumnya. Pada zaman kerajaan sebelum Indonesia merdeka, Sumenep merupakan pusat pemerintahan di Madura. Kabupaten Sumenep merupakan wilayah yang unik karena terdiri wilayah daratan dengan pulau yang tersebar berjumlah 126 pulau. Sebenarnya dengan potensi kepulauan, Kabupaten Sumenep dapat mengembangkan pariwisata mengikuti Destinasi Wisata Kepulauan Seribu dan Taman Nasional Bunaken karena Sumenep kaya akan terumbu karang. Kabupaten Sumenep juga dikenal dengan semboyan Sumekar "Sumenep Karaton" karena terdapat peninggalan puluhan Kraton/istana Adipati. Masyarakat Sumenep juga sangat menjunjung tinggi tatakrama dan bahasa, sebagaimana lazimnya wilayah kerajaan atau kesultanan. Bahasa Madura halus menjadi bahasa yang digunakan sehari-hari oleh masyarakat Sumenep. Saat ini di Sumenep juga terdapat bandar udara komersil, yaitu Bandar Udara Trunojoyo.

4. Kabupaten Bangkalan dan Kabupaten Sampang masuk kategori Kuadran IV yaitu daerah relatif tertinggal dengan indikator IPM rendah dan laju pertumbuhan ekonomi juga rendah.

Temuan ini selain cukup mengejutkan juga sangat menarik untuk dikaji lebih lanjut sebab Kabupaten Bangkalan (utamanya) adalah kabupaten yang paling dekat dengan pusat Provinsi Jawa Timur. Terlebih sejak beroperasinya Jembatan Suramadu, Bangkalan telah "tersambung" dengan Surabaya. Akses yang begitu mudah dan cepat seharusnya menjadi pemicu kemajuan Kabupaten Bangkalan dapat lebih pesat dibandingkan tiga kabupaten yang lain. Akan tetapi yang terjadi adalah sebaliknya, Bangkalan justru menjadi kabupaten tertinggal. Di Bangkalan juga berdiri sebuah Universitas Negeri yang cukup ternama, yaitu Universitas Trunojoyo (UNIJOYO) dan sebuah kampus swasta yang mencetak sumber daya pendidik yaitu STKIP PGRI Bangkalan, seharusnya kedua lembaga pendidikan ini dapat menjadi mesin pendorong kemajuan Kabupaten Bangkalan yang berfungsi lebih optimal, khususnya dalam hal pembangunan manusia. Berdasarkan wawancara dengan seorang nara sumber di salah satu instansi pemerintah di Kabupaten Bangkalan, Bangkalan sulit berkembang karena faktor politik, Bangkalan sangat membutuhkan Good Government and Good Governance. Lebih jauh tentang Kabupaten Bangkalan, merupakan wilayah kerajaan Madura Barat, dan sangat terkenal dengan kebudayaan Karapan Sapi serta industri batik tulis. Di Bangkalan juga terdapat wisata kampung batik, yaitu di sentra industri batik tulis Kecamatan Tanjung Bumi. Bangkalan juga terkenal dengan produk perkebunannnya, yaitu Salak Bangkalan. Sebenarnya Kabupaten Bangkalan memiliki potensi sektoral yang sangat besar untuk dikembangkan dalam rangka akselerasi kemajuan Kabupaten Bangkalan. 
Adapun Kabupaten Sampang, sesuai dengan persepsi masyarakat bahwa Sampang adalah kabupaten yang paling tertinggal di Madura. Persepsi ini pun sesuai dengan data yang ada, dimana IPM Kabupaten Sampang menempati posisi terendah di Jawa Timur. Temuan ini juga sangat menarik untuk dikaji lebih lanjut mengingat Sampang berada diantara pintu gerbang Madura (Bangkalan) dan kabupaten paling maju di Madura (Pamekasan). Kedekatan jarak seharusnya dapat menjadi salah satu pemicu semakin berkembangnya Kabupaten Sampang. Di Kabupaten Sampang juga terdapat ladang minyak dan gas bumi, yaitu Sumur Gas Oyong. Lain itu juga terdapat perusahaan migas seperti Santos Sampang, Singapore Petroleum Company Limited, Cue Sampang, Petrogas Oyong, dan PT Sampang Mandiri Perkasa. Di Kabupaten Sampang juga terdapat bandar udara heliport di Shorebase Camplong. Potensi minyak dan gas bumi rupanya belum bisa menjadikan Kabupaten Sampang menjadi kabupaten yang kaya dan maju. Dalam hal ini dapat dikaji lebih lanjut mengenai kontribusi kegiatan Corporate Social Responsibility (CSR) yang merupakan kewajiban dari perusahaan terhadap upaya pemberdayaan kualitas masyarakat dan lingkungan. Seharusnya hadirnya berbagai perusahaan migas dapat membawa dampak positif bagi masyarakat sekitar.

Temuan penelitian ini mengkoreksi temuan penelitian sebelumnya yang dilakukan pada kurun waktu 2005-2009 bahwa dengan analisis tipologi klassen di Pulau Madura dapat diklasifikasikan menjadi empat pola pertumbuhan ekonomi, yaitu : 1) daerah cepat maju dan cepat tumbuh yaitu kabupaten Bangkalan, 2) Daerah berkembang cepat adalah Kabupaten Pamekasan, 3) Daerah maju tetapi tertekan adalah Kabupaten Sumenep, dan 4) daerah relatif tertinggal adalah Kabupaten Sampang (Nur, 2011). Yang menjadi sorotan dalam hal ini adalah penurunan signifikan yang dialami Kabupaten Bangkalan dimana lima tahun sebelumnya (2009) berada di kuadran I kemudian turun menjadi kuadran IV. Tampak pula peningkatan signifikan pada Kabupaten Pamekasan yang sebelumnya di kuadran II menjadi kuadran I. Adapun untuk Kabupaten Sumenep dan Kabupaten Sampang relatif stagnan.

Implikasi dari temuan ini adalah bahwa posisi kualifikasi pola pertumbuhan ekonomi dari suatu daerah dinamis. Berbagai upaya yang dilakukan oleh suatu daerah dapat mendorong daerah tersebut untuk berpindah kuadran menuju kualifikasi yang lebih baik. Sebaliknya daerah yang mengalami stagnansi atau justru penurunan kualifikasi dalam beberapa tahun berjalan menunjukkan terdapat masalah yang perlu ditangani segera oleh pemerintah setempat.

\section{E. SIMPULAN}

Berdasarkan pembahasan, dapat disimpulkan hasil penelitian sebagai berikut : klasifikasi wilayah berdasar tipologi klassen membagi Pulau Madura menjadi tiga klasifikasi, yaitu : 1) Kuadran I (daerah cepat maju dan cepat tumbuh) adalah 
Kabupaten Pamekasan, 2) Kuadran III (daerah tertekan) adalah Kabupaten Sumenep, dan 3) Kuadran IV (daerah relatif tertinggal) adalah Kabupaten Bangkalan dan Kabupaten Sampang. Kabupaten Pamekasan mengalami peningkatan kualifikasi dari lima tahun sebelumnya, Kabupaten Sumenep dan Kabupaten Sampang stagnan, adapun Kabupaten Bangkalan justru mengalami kemunduran.

\section{DAFTAR PUSTAKA}

Badan Pusat Statistik. (2015). Indeks Pembangunan Manusia 2014. Jakarta: Badan Pusat Statistik.

Badan Pusat Statistik Provinsi Jawa Timur. (2018). Jawa Timur Dalam Angka 2018. Jawa Timur: BPS Provinsi Jawa Timur.

Bemby, B., \& Bashir, A. (2015). Analisis Tipologi dan Hubungan antara Indeks Pembangunan Manusia dan Pertumbuhan Ekonomi di Provinsi Sumatera Selatan. Jurnal Ekonomi Pembangunan Vol 13 No 1 Juni 2015, 21-36.

BPS Kabupaten Bangkalan. (2018). Kabupaten Bangkalan dalam Angka 2018. Bangkalan: BPS Kabupaten Bangkalan.

Kuncoro, M. (2019). Ekonomi Regional Teori dan Praktik. Depok: PT Rajagrafindo Persada.

Latuconsina, Z. M. (2017). Analisis Faktor-faktor yang Mempengaruhi Indeks Pembangunan Manusia Kabupaten malang Berbasis Pendekatan Perwilayahan dan Regresi Panel. Journal of Regional and Rural Development Planning Vol 1 No 2 Juni 2017 , 202-216.

Lisbet. (2013). Pencapaian Millenium Development Goals (MDGs) di Indonesia melalui Kerjasama Internasional. Politica Vol 4 No 1 Mei 2013 , 129-156.

Lumbantoruan, E. P., \& Hidayat, P. (2014). Analisis Pertumbuhan Ekonomi dan Indeks Pembangunan Manusia (IPM) Provinsi-provinsi di Indonesia (Metode Kointegrasi). Jurbal Ekonomi dan Keuangan Vol 2 No 2 , 14-27.

Nur, A. F. (2011). Analisis Potensi Sektoral pada Empat Kabupaten di Pulau Madura. Jurnal Ekonomi Pembangunan Vol 9 No 1 Juli 2011 , 21-41. 
Sukirno, S. (2019). Makro Ekonomi Teori Pengantar Edisi Ketiga. Jakarta: PT RajaGrafindo Persada.

Todaro, M. P., \& Smith, S. C. (2016). Pembangunan Ekonomi Edisi Kesebelas Jilid I. Jakarta: Erlangga. 